\title{
Time-transgressive Onset of the Holocene Optimum in the East Asian Monsoon Region
}

\author{
Xin Zhou ${ }^{\text {a }}$, Liguang Sun ${ }^{\text {a* }}$, Tao Zhan ${ }^{b}$, Wen Huang ${ }^{a}$, Xinying Zhou ${ }^{c}$, Qingzhen \\ Hao ${ }^{\mathrm{d}}$, Yuhong Wang ${ }^{\mathrm{a}}$, Xiaoqing $\mathrm{He}^{\mathrm{a}}$, Chao Zhao ${ }^{\mathrm{c}}$, Jun Zhang ${ }^{\mathrm{b}}$, Yansong Qiao ${ }^{\mathrm{e}}$, \\ Junyi Ge ${ }^{\mathrm{c}}$, Pei Yan ${ }^{\mathrm{a}}$, Qing Yan ${ }^{\mathrm{f}}$, Da Shao ${ }^{\mathrm{a}}$, Zhuding Chu ${ }^{\mathrm{a}}$, Wenqing Yang ${ }^{\mathrm{a}}$, John P. \\ $\mathrm{Smol}^{\mathrm{g}}$
}


Abstract: The East Asian summer monsoon affects precipitation and hence vegetation in the densely populated Northwest Pacific region, yet a long-standing controversy exists concerning the spatial and temporal dynamics of the Holocene Optimum (HO) in the East Asian Monsoon Region. Here we use a detailed 14,000-year record reconstructing vegetation variations from a strategically selected crater lake from Northeast China, as well as a compilation of previous paleoclimatic studies, to show that the $\mathrm{HO}$ began around 6,000 Cal a BP in Northeast China, significantly later than generally recognized. By comparing our paleoenvironmental data with Holocene vegetation records from other regions of East Asia, we identified a marked northward shift for the onset of the $\mathrm{HO}$ from $\sim 10,260 \mathrm{Cal}$ a BP in South China to $\sim 6,000 \mathrm{Cal}$ a BP in Northeast China. The gradual northward transgression of the vegetation change could be caused by both the temperature and precipitation changes in different regions. Finally, we fitted a regression model of the start of the HO period versus latitude, which allowed us to make predictions for the beginning of the $\mathrm{HO}$ based at different geographical locations. This study reveals a strong relationship between latitude and the initiation of the $\mathrm{HO}$, and provides a window towards better understanding the forcing of vegetation changes in the East Asian monsoon region.

Keywords: East Asian monsoon region; Holocene Optimum; vegetation; seasonal insolation 


\section{Introduction}

The East Asian monsoon (EAM) region is a unique geographic area that encompasses mid-latitude areas where the summer monsoon can reach as far north as $55^{\circ} \mathrm{N}$ (Wang, 2006). As it transports heat and moisture from ocean to land, the summer monsoon controls climatic, ecological and social variations, including air temperature, rainfall amount and vegetation development. Understanding EAM dynamics, and particularly the factors that cause variations in terrestrial vegetation cover closely linked to monsoon strength and human activities, is critical to human lives and agricultural and industrial activities in the densely populated Northwest Pacific region.

The early- to mid-Holocene has generally been characterized as a warm period (Renssen et al., 2012), and has thus been considered as a possible "analog" for recent global warming, although some models have challenged this view (Liu et al., 2014). From a series of temperature records reconstructed from pollen percentages, earlier studies found a "Holocene Megathermal" between 8.0 and 3.0 ka in China (Shi et al., 1993). With the increasing availability of high-resolution records of past climate changes in the East Asian monsoon region, its spatiotemporal patterns and dynamics during the Holocene have been extensively studied, but a wide range of patterns have been suggested. For example, using a large number of East Asian summer monsoon records, particularly pollen records, An et al (2000) found a time-transgressive Holocene Optimum (HO) of the EAM region, which was attributed to low latitude forcing — the southeastward shift of the monsoon front and weakening of summer insolation. More recent studies (Zhao et al., 2009; Zhou et al., 2007) concluded that the HO related to vegetation in both south and north China were forced by low latitude summer insolation and were nearly synchronous around 9,000 Cal a BP. With the increased availability of well-dated records in northeastern China, using synthetic Holocene moisture records, Ran and Feng (2013) found that the duration of the HO in northern China ( 9.5-5 ka BP) differed from that in southern China ( 11-4 ka BP), and attributed this difference to the forcing of gradual changes in low latitude sea 
surface temperature (SST) in response to summer insolation. Proxies used in these studies were generally linked to moisture/precipitation changes, and thus HO was defined as period with high monsoon precipitation in the Holocene. However, some of these proxies were still questionable; thus it is better to define $\mathrm{HO}$ according to a single certain proxy. Furthermore, partly due to the lack of a sufficient number of precisely-dated, high-resolution records, especially from higher latitudes in northeastern China, a wide range of spatiotemporal patterns of the HO have been proposed. This limits our understanding of the spatiotemporal patterns and forcing of the vegetation cover changes during the Holocene.

Here, we reconstructed a 14,000-year vegetation record from a lake sediment core collected in northeastern China of high latitude. In the present study, we define the $\mathrm{HO}$ according to only one proxy of pollen percentage. Our record, in combination with previous records from lower latitude regions, provides a more comprehensive record of the $\mathrm{HO}$ throughout the EAM region and an opportunity to more precisely explore Holocene vegetation changes in the EAM region.

\section{Study site, materials and methods}

Nagelaqiu Hill $\left(126.00^{\circ} \mathrm{E}, 48.74{ }^{\circ} \mathrm{N}\right)$, a $149.9 \mathrm{~m}$ high volcano of $596.9 \mathrm{~m}$ elevation, located in the Wudalianchi Global Geopark, Heilongjiang Province in Northeastern China (Figure 1), has erupted at $~ 0.8$ Ma BP (Gong, 1997) and 0.46 Ma BP (Liu, 1987). The hill is located in a typical temperate monsoon region, where the annual average air temperature is $0-0.5^{\circ} \mathrm{C}$, and the average precipitation is $\sim 470$ $\mathrm{mm}$ (Figure 2). The forest in this area is composed mainly of birch and oak, which are distributed on and around the hill. Tianchi Lake, on the top of the Nangelaqiu Hill, is a typical crater lake with a diameter of $\sim 400 \mathrm{~m}$. The lake was made available for irrigation in the 1970s, and is thus swampy now.

Two sediment cores, labeled as TC1 (309 cm compressed to $197 \mathrm{~cm}$ long, drilled for two times) and TC2 (500 cm long, drilled for five times, only the upper $306 \mathrm{~cm}$ is 
used in this study), were collected from Tianchi Lake, using a $55 \mathrm{~mm}$ diameter percussion corer in October 2011 and November 2012, respectively. The upper 125 $\mathrm{cm}$ of Core TC1 is grey yellow in colour, with substantial organic residues. The part below $125 \mathrm{~cm}$ is black, and contains red clastic volcanic particles of $<2 \mathrm{~mm}$ diameter. Lithology of Core TC2 is similar to that of TC1. Both of the cores were sectioned at $0.5 \mathrm{~cm}$ intervals resulting in a total of 984 subsamples.

$\mathrm{LOI}_{550^{\circ} \mathrm{C}}$ for 764 samples was analyzed at the Institute of Polar Environment, USTC, Hefei, China. Samples of the Core TC1 were measured at approximately 0.5 $\mathrm{cm}$ intervals. For Core TC2, samples were analyzed at $0.5 \mathrm{~cm}$ and $1 \mathrm{~cm}$ intervals above and below $103 \mathrm{~cm}$, respectively. The samples were homogenized using a mortar and pestle, and passed through a 120- $\mu \mathrm{m}$ sieve. 0.5-1.0 g samples were heated to $105^{\circ} \mathrm{C}$ for $12 \mathrm{~h}$ to constant weight, then combusted to $550^{\circ} \mathrm{C}$ for about $2 \mathrm{~h}$ to a constant weight in crucible, from which the $\mathrm{LOI}_{550^{\circ} \mathrm{C}}$ was calculated. The analysis error is smaller than $1 \%$.

374 samples of Core TC1 were analyzed for TOC. For pre-treatment, $10 \mathrm{ml} \mathrm{HCL}$ solution (10\%) was added to remove calcareous cement. The samples were subsequently ground and passed through a 200-mesh sieve. Carbon content was measured by Vario EL III(Elementar Company) with an error smaller than $1 \%$.

A total of 48 samples of the Core TC2 at $5 \mathrm{~cm}$ intervals were collected for pollen analysis. Pollen samples were processed using heavy liquid separation (Moore and Webb, 1978) and acetolysis (Erdtman, 1960). Lycopodium tablets were added to the samples to allow for the calculation of pollen concentrations (Peck, 1974). At least 300 pollen grains were counted for each sample.

Measurements of low frequency magnetic susceptibility for Core TC1 were carried out using the Bartington MS2 susceptibility meter. In total 367 samples were measured for magnetic susceptibility.

AMS ${ }^{14} \mathrm{C}$ dating was carried out on 14 samples using TOC, plant residues or seeds at the University of Georgia. The result was calibrated to calendar age by the calibration curve IntCal13 (Reimer et al., 2013).

To study the spatial distribution of the beginning of the HO, published vegetation 
proxies in the EAM region were collected based on the following criteria: 1) all the study sites are located in the EAM region; 2) elevation of the sites are lower than $2,000 \mathrm{~m}$, so as to minimize the impact of elevation on vegetation changes; 3 ) high-resolution and precise dating are available; 4) chronology at each site covers the entire Holocene; 5) pollen profiles are available at all sites, and TOC profiles are available at some of the sites; and 6) the average temporal resolution of the proxies are higher than $200 \mathrm{yr}$. In total, nine sites were selected (Table 1).

Because vegetation is generally most developed under optimum climate (warm and humid climate), we define the $\mathrm{HO}$ as the period with the highest vegetation cover during the Holocene. To determine the initial age of the $\mathrm{HO}$ in the vegetation profiles at different latitudes, we first extract trend of each record using the method of Singular Spectrum Analysis (Ghil et al., 2004), which can decompose a time-series into different components, including the trends, oscillatory components, and noises. Then the profiles were normalized by the equation: $\mathrm{V}=\left(\mathrm{V}_{\mathrm{i}}-\mathrm{V}_{\min }\right) /\left(\mathrm{V}_{\max }-\mathrm{V}_{\min }\right)$, where $\mathrm{V}_{\min }$ is the lowest value between 10,000 and 12,000 Cal a BP and $\mathrm{V}_{\max }$ the highest value in the Holocene. We then identified a range of depths over which the onset of $\mathrm{HO}$ occurs using $0.5-0.7$ as a range of thresholds. After that a depth was randomly picked in the range of depths using a program, and the corresponding age and age uncertainty of the random depth was calculated. At last we repeated pick depth randomly and calculate corresponding age for 1000 times and then calculate the mean value of age and standard deviation (Yan et al., 2011).

\section{Results and Discussion}

\subsection{Chronology}

Fourteen AMS ${ }^{14} \mathrm{C}$ ages from Core TC1 (Table 2, Figure 3) were ordered chronologically from the bottom to the top, except for the one sample at the bottom of the core which was obtained from plant residues. The corer may have carried plant 
residues from the upper layers to the bottom when the core was taken. Therefore, the AMS ${ }^{14} \mathrm{C}$ age of the bottom sample obtained from plant residues was removed, and the age of the basal age was dated as $13,700 \mathrm{Cal}$ a $\mathrm{BP}$ using a bulk ${ }^{14} \mathrm{C}$ date. Sedimentation rates for the 0-16 cm depth, $16-83 \mathrm{~cm}$ depth, $83-177 \mathrm{~cm}$ depth, 177-184 cm depth and $184 \mathrm{~cm}$ depth to the bottom depth intervals were estimated to be $\sim 0.09 \mathrm{~cm} \cdot \mathrm{yr}^{-1}, \sim 0.01 \mathrm{~cm} \cdot \mathrm{yr}^{-1}, \sim 0.02 \mathrm{~cm} \cdot \mathrm{yr}^{-1}, \sim 0.002 \mathrm{~cm} \cdot \mathrm{yr}^{-1}$ and $\sim 0.02 \mathrm{~cm} \cdot \mathrm{yr}^{-1}$, respectively.

A black and well-sorted sand layer, markedly different from other parts of the sediment, was present at the 16-18 cm depth of Core TC1. Sediments in the layer had much higher magnetic susceptibility than in other parts of the core (Figure 4), suggesting that the sand was derived from volcanic rock, which contains magnetic minerals. Rocks of the Nangelaqiu Hill are red, and those around Tianchi Lake are not well sorted. Thus the sand layer was not composed of rocks from the Nangelaqiu Hill, but must be airborne material, since Tianchi Lake is as a crater lake. As documented by historical archives, Laoheishan Hill, about $9 \mathrm{~km}$ southwest of Nangelaqiu Hill, erupted during 1720-1721 AD (Chen et al., 1999). The AMS ${ }^{14} \mathrm{C}$ age of the upper part of the sand layer is 144-215 Cal a BP (1735-1806 AD), consistent with the eruption age of Laoheishan Hill (Figure 4). The volcanic sand layer thus provides a precise and absolute age for the sediments, and thus also confirms that our AMS ${ }^{14} \mathrm{C}$ age is reliable.

Because there are no AMS ${ }^{14} \mathrm{C}$ ages for Core $\mathrm{TC} 2$, we chose $\mathrm{LOI}_{550^{\circ} \mathrm{C}}$ as a proxy for comparison between cores TC1 and TC2 (Figure 5). Trends of $\mathrm{LOI}_{550^{\circ} \mathrm{C}}$ time-series of the two cores are similar, and the values are consistent. Peaks and valleys on millennial and centurial time scales are clearly comparable. We thus aligned the $\mathrm{LOI}_{550^{\circ} \mathrm{C}}$ of TC2 onto that of TC1 to obtain a chronology for samples in TC2.

\subsection{Pollen records in lake sediments}

Pollen is widely used for reconstructing vegetation and climatic changes (An et al., 2000; Zhao et al., 2009). In our TC1 and TC2 sediment cores, tree pollen percentage, TOC and $\mathrm{LOI}_{550^{\circ} \mathrm{C}}$ showed strong correlations with each other and 
exhibited similar trends (Figure 6), which is consistent with earlier studies (Santisteban et al., 2004). TOC in lake sediments has also been used as proxy for vegetation shifts (An et al., 2011; Xiao et al., 2006), but other factors may also influence the TOC concentrations (Smol, 2008). So though TOC and $\mathrm{LOI}_{550^{\circ} \mathrm{C}}$ showed strong correlations with tree pollen percentage, we used pollen as vegetation proxy, and used TOC and $\mathrm{LOI}_{550^{\circ} \mathrm{C}}$ for stratigraphic correlation only (Figure 5).

Time-series analysis of tree pollen showed low tree pollen percentages during the early Holocene (Figure 7). Around 6,000 BP, tree pollen started to increase rapidly and reached its peak between 5,500 and 4,000 BP. Similar to tree pollen percentages, pollen percentages of broadleaf trees (Figure 8) were low during the early Holocene, and were high during mid- to late-Holocene. Pollen percentages of some typical trees (Figure 8) also showed similar trends. And some taxa, including Chenopodiaceae and Polygonaceae, were lower during the mid-Holocene, showing nearly inversed trend to broadleaf trees.

Tree pollen percentages in lake sediments in the EAM region have generally been used as proxy for moisture changes (Zhao et al., 2009). Moreover, studies on selected pollen taxa from northern China showed that pollen percentages of Pinus and Betula are positively correlated with precipitation, and those of Chenopodiaceae are negatively correlated with precipitation (Sun et al., 1996). Therefore, relatively higher pollen percentages of trees (Figure 7), broadleaf trees and typical trees, including Pinus and Betula (Figure 8), together with lower pollen percentages of Chenopodiaceae (Figure 8), might indicated more moisture climate during mid- to late-Holocene.

\subsection{Spatiotemporal pattern of the HO in the EAM region}

The highest tree pollen percentages in Tianchi Lake at $\sim 5,000 \mathrm{Cal}$ a BP is temporally consistent with the findings in the other two lakes (Moon Lake and Sihailongwan Lake) in northeastern China (Figure 9). Surprisingly, although Tianchi Lake is located in the modern EAM region, the temporal trends of tree pollen percentages are significantly different from other generally used monsoon proxies 
such as stalagmite $\delta^{18} \mathrm{O}$ and synthesized monsoon indices from records in eastern China (Figure 7). The period of tree pollen peaks between 5,500 years and 2,000 years BP can be considered as the HO in our records, which was about 5,000 years later than proxies reconstructed in other parts of the EAM region (Figure 7). The inconsistence is partly attributed to the following two reasons. Firstly, stalagmite $\delta^{18} \mathrm{O}$ might not be a good proxy of summer monsoon precipitation in some part of the EAM region during the Holocene, as indicated in earlier studies (Chen et al., 2015; Liu et al., 2015). Secondly, spatiotemporal patterns of the HO have not been fully considered during synthesis of monsoon indices.

To illustrate the spatiotemporal patterns of vegetation level in the EAM region, we compared pollen records in our sediment samples with those of earlier studies (Figure 9), all of which were at least 10,000 years old (Table 1). Remarkably, the initiation of the $\mathrm{HO}$ (Figure 9c) from different locations show a highly significant correlation with latitude $(\mathrm{r}=-0.93, \mathrm{P}<0.0003)$. Based on this linear relationship, we estimated that the initiation of the HO in the EAM region moved northward at a relatively constant rate of $\sim 180$ years per degree latitude. The meridional variability of the initiation of the HO is significantly different from earlier results (An et al., 2000; Zhao et al., 2009; Zhou et al., 2007), which found a southeastern shift or nearly synchronous timing of the HO. The differences might be due to the fact that earlier studies used different proxies and had chronological problems (Liu et al, 2015).

To test the proposed linear relationship between the timing of the initiation of the $\mathrm{HO}$ and latitude, the timing of the $\mathrm{HO}$ in loess sections was inferred based on the presence of paleosol layers. Paleosol layers in loess are formed during warm and wet periods, thus the timing of their initiation also serves as a proxy for the beginning of the HO (An et al., 2000). We collected data from four loess sections, ages of which were determined by high-resolution optically stimulated luminescence (OSL). Based on their latitudes, the beginnings of the predicted $\mathrm{HO}$ were remarkably consistent with the initial timing of soil development, as determined by OSL dating (Figure 9c, Table 3). The time-transgressive pattern of the $\mathrm{HO}$ is consistent with that of the Pleistocene/Holocene transition recorded by magnetic susceptibility of Chinese loess 
in a recent study (Dong et al., 2015). This confirms our suggestion of a gradually northward transgression of the $\mathrm{HO}$ in the EAM region in the early- to mid-Holocene.

\subsection{Possible dynamics of spatiotemporal pattern of the HO}

We first propose that the spatiotemporal pattern of the HO initial times is forced by the shrinkage of the northern hemisphere ice sheet, because 1) Tianchi Lake is located at nearly $50{ }^{\circ} \mathrm{N}$, where northern ice sheet has the potential to influence the climate; 2) studies (Peltier, 2004; Törnqvist and Hijma, 2012) have shown that northern hemisphere ice sheet shrank gradually in early to mid Holocene; and 3) earlier studies (Wen et al., 2010) have considered that weak monsoon strength in early Holocene in northern China might be resulted from the existence of remnant northern hemisphere ice sheet. However, shrinkage of the northern hemisphere ice sheet in early to mid Holocene occurred mainly in North America (Peltier, 2004; Törnqvist and Hijma, 2012), which has been shown to have little influence on East Asian summer monsoon strength (Sundaram et al., 2012).

To mechanistically understand the spatiotemporal pattern of vegetation change over the last 14,000 years, we second considered the influence of summer monsoon, which brings precipitation to the EAM region. Kutzbach (1981) suggested that the summer monsoon is driven by low-latitude summer insolation through land-ocean thermal contrasts, and that there are few phase lags $(\sim 2,000-3,000$ years) between them. Methane concentrations in ice cores, the Dole effect, stalagmite $\delta^{18} \mathrm{O}$ in China and modeling results all support this hypothesis (Kutzbach et al., 2008; Ruddiman, 2006). However, our reconstruction of spatiotemporal change of the HO was significantly different from summer insolation records (Figure 7), suggesting that the $\mathrm{HO}$ in the EAM region may be under different control.

Both temperature and precipitation have significant impact on vegetation and contribute to the gradual transgression of the HO. In southern China, the initiation of the HO in southern China could be attributed to both higher monsoon precipitation and higher temperature in the early Holocene (Wang et al., 2016; Wu et al., 2012; Xie et al., 2013). Since monsoon precipitation is high in southern China, plant growth 
might be controlled more by temperature. In northern China, precipitation might be the limiting factor for plant growth because of low rainfall. Therefore, the changes in tree pollen percentages in northern China are well correlated to those in monsoon precipitation, in consistence with records from other sites such as Gonghai (Chen et al., 2015) and Sihailongwan (Stebich et al., 2015). The initiation time of the HO at $\sim 8,000-7,000 \mathrm{Cal}$ a $\mathrm{BP}$ around $40^{\circ} \mathrm{N}$ in northern China is expected to be related to strengthen of the East Asian summer monsoon (Chen et al., 2015; Liu et al., 2015). The even later initiation time of the $\mathrm{HO}$ at $\sim 5,000$ Cal a $\mathrm{BP}$ around $48{ }^{\circ} \mathrm{N}$ in northeastern China might be ascribed to a more complicated forcing of monsoon precipitation, such as the influence of Okhotsk High (Ding et al., 1994).

Interestingly, a time-transgressive termination of the humid period in the Holocene in the humid tropical West Africa has been reported, and it was attributed to a southward migration of the northernmost seasonal limit of the tropical rainbelt (Shanahan et al., 2015). Therefore, though the regional differences in temperature-precipitation changes exists, the linear relationship between initiation times of the $\mathrm{HO}$ and latitudes might be mainly driven by seasonal insolation changes. Further studies are apparently needed.

\section{Conclusions}

In summary, we describe a pattern of a gradual northward expansion of the $\mathrm{HO}$ and propose a mechanism showing how seasonal insolation may influence EAM rainfall. The fitted regression model of the initiation of the $\mathrm{HO}$ versus latitude can be used to predict the beginning of the HO based at different geographical locations in the EAM region. Our study highlights strong regional variability and shows that monsoon precipitation in different parts of the EAM region is controlled by both temperature and precipitation. The physical mechanisms of gradually northward expansion of the $\mathrm{HO}$ in the EAM region should be further investigated, and our study has the potential to provide a better understanding of vegetation dynamics associated with regional temperature-precipitation changes. 


\section{Acknowledgements}

316 This study is jointly supported by Chinese Academy of Sciences (XDA11030104), the

317 National Basic Research Program of China (2015CB953802), the Chinese Polar 318 Environment Comprehensive Investigation \& Assessment Programmes 319 (CHINARE2013-04-03-07), the Ministry of Land and Resources (201311137) and 320 National Science Foundation of China (41102223, 41301040, and 41472149). We 321 thank Shouli Yang, Chunlai Yang, and Guoqiang Chu, for their invaluable assistance 322 in the field and core sampling. 


\section{References}

An, Z., Clemens, S.C., Shen, J., Qiang, X., Jin, Z., Sun, Y., Prell, W.L., Luo, J., Wang, S., Xu, H., Cai, Y., Zhou, W., Liu, X., Liu, W., Shi, Z., Yan, L., Xiao, X., Chang, H., Wu, F., Ai, L., Lu, F., 2011. Glacial-interglacial Indian Summer monsoon dynamics. Science 333, 719-723.

An, Z., Porter, S.C., Kutzbach, J.E., Xihao, W., Sumin, W., Xiaodong, L., Xiaoqiang, L., Weijian, Z., 2000. Asynchronous Holocene optimum of the East Asian monsoon. Quaternary Science Reviews 19, 743-762.

Chen, F., Xu, Q., Chen, J., Birks, H.J.B., Liu, J., Zhang, S., Jin, L., An, C., Telford, R.J., Cao, X., Wang, Z., Zhang, X., Selvaraj, K., Lu, H., Li, Y., Zheng, Z., Wang, H., Zhou, A., Dong, G., Zhang, J., Huang, X., Bloemendal, J., Rao, Z., 2015. East Asian summer monsoon precipitation variability since the last deglaciation. Scientific Reports 5, 11186.

Chen, F., Yu, Z., Yang, M., Ito, E., Wang, S., Madsen, D.B., Huang, X., Zhao, Y., Sato, T., Birks, H.J.B., Boomer, I., Chen, J., An, C., Wünnemann, B., 2008. Holocene moisture evolution in arid central Asia and its out-of-phase relationship with Asian monsoon history. Quaternary Science Reviews 27, 351-364.

Chen, H., Ren, J., Wu, X., 1999. Volcanic eruptive processes and characteristics of the current volcanoes in the Wudalianchi Volcano Clusters known from Manchurian-Language historical archives discovered at present. Geological Review 45, 409-413.

Ding, Y., 1994. Monsoons over China. Springer, Heidelberg.

Dong, Y., Wu, N., Li, F., Huang, L., Wen, W., 2015. Time-transgressive nature of the magnetic susceptibility record across the Chinese Loess Plateau at the Pleistocene/Holocene transition. PLoS ONE 10, e0133451.

Erdtman, G., 1960. The acetolysis method, A revised description. Svensk Botanisk Tidskrift 54, 561-564.

Ghil, M., Allen, M.R., Dettinger, M.D., Ide, K., Kondrashov, D., Mann, M.E., Robertson, A.W., Saunders, A., Tian, Y., Varadi, F., Yiou, P., 2004. Advanced 
spectral methods for climatic time series. Reviews of Geophysics 40, 1003. doi, 10.1029/2000RG000092.

Gong, J., 1997. Tectonic setting, age and type of Wudalianchi Volcanoes. Heilongjiang Geology 8, 19-28.

Jia, Y., Huang, C., Mao, L., 2011. OSL dating of a Holocene loess-paleosol sequence in the southern Loess Plateau, China. Environmental Earth Sciences 64, 1071-1079.

Jiang, W., Guo, Z., Sun, X., Wu, H., Chu, G., Yuan, B., Hatte, C., Guiot, J., 2006. Reconstruction of climate and vegetation changes of Lake Bayanchagan (Inner Mongolia): Holocene variability of the East Asian monsoon. Quaternary Research $65,411-420$.

Kutzbach, J.E., 1981. Monsoon climate of the early Holocene: climate experiment with Earth's orbital parameters for 9000 years ago. Science 214, 59-61.

Kutzbach, J.E., Liu, X., Liu, Z., Chen, G., 2008. Simulation of the evolutionary response of global summer monsoons to orbital forcing over the past 280,000 years. Climate Dynamics 30, 567-579.

Laskar, J., Robutel, P., Joutel, F., Gastineau, M., Correia, A.C.M., Levrard, B., 2004. A long-term numerical solution for the insolation quantities of the Earth. Astronomy and Astrophysics 428, 261-285.

Liu, J., 1987. Study on geochronology of the Cenozoic volcanic rocks in Northeast China. Acta Petrologica Sinica, 21-31.

Liu, J., Chen, J., Zhang, X., Li, Y., Rao, Z., Chen, F., 2015. Holocene East Asian summer monsoon records in northern China and their inconsistency with Chinese stalagmite $\delta^{18} \mathrm{O}$ records. Earth-Science Reviews, 148, 194-208.

Liu, Q., Li, Q., Wang, L., Chu, G., 2010. Stable carbon isotope record of bulk organic matter from a sediment core at Moon Lake in the middle part of the Daxing'an Mountain range, Northeast China during the last 21 ka. Quaternary Sciences 30, 1069-1077.

Liu, Z., Zhu, J., Rosenthal, Y., Zhang, X., Otto-Bliesner, B.L., Timmermann, A., Smith, R.S., Lohmann, G., Zheng, W., Timm, O.E., 2014. The Holocene 
temperature conundrum. PNAS 111, E3501-E3505.

Lu, H., Yi, S., Liu, Z., Mason, J.A., Jiang, D., Cheng, J., Stevens, T., Xu, Z., Zhang, E., Zhang, Z., Guo, Z., Wang, Y., Otto-Bliesner, B., 2013. Variation of East Asian monsoon precipitation during the past $21 \mathrm{k} . \mathrm{y}$. and potential $\mathrm{CO}_{2}$ forcing. Geology 41, 1023-1026.

Moore, P.D., Webb, J.A., 1978. An illustrated guide to pollen analysis. Hodder and Stoughton, London.

Peck, R.M., 1974. A comparison of four absolute pollen preparation techniques. New Phytologist 73, 567-587.

Peltier, W.R., 2004. Global glacial isostasy and the surface of the ice-age Earth: the ICE-5G (VM2) model and GRACE. Annual Review of Earth and Planetary Sciences 32, 111-149.

Ran, M., Feng, Z., 2013. Holocene moisture variations across China and driving mechanisms: A synthesis of climatic records. Quaternary International 313-314, 179-193.

Reimer, P.J., Bard, E., Bayliss, A., Beck, J.W., Blackwell, P.G., Ramsey, C.B., Buck, C.E., Cheng, H., Edwards, R.L., Friedrich, M., Grootes, P.M., Guilderson, T.P., Haflidason, H., Hajdas, I., Hatté, C., Heaton, T.J., Hoffmann, D.L., Hogg, A.G., Hughen, K.A., Kaiser, K.F., Kromer, B., Manning, S.W., Niu, M., Reimer, R.W., Richards, D.A., Scott, E.M., Southon, J.R., Staff, R.A., Turney, C.S.M., Plicht, J.v.d., 2013. INTCAL13 and MARINE3 radiocarbon age calibration curve 0-50,000 years cal BP. Radiocarbon 55, 1869-1887.

Renssen, H., Seppä, H., Crosta, X., Goosse, H., Roche, D.M., 2012. Global characterization of the Holocene Thermal Maximum. Quaternary Science Reviews 48, 7-19.

Ruddiman, W.F., 2006. What is the timing of orbital-scale monsoon chages? Quaternary Science Reviews 25, 657-658.

Santisteban, J.I., Mediavilla, R., López-Pamo, E., Dabrio, C.J., Zapata, M.B.R., García, M.J., Castaño, S., Martínez-Alfaro, P.E., 2004. Loss on ignition: a qualitative or quantitative method for organic matter and carbonate mineral 
content in sediments? Journal of Paleolimnology 32, 287-299.

Shanahan, T.M., McKay, N.P., Hughen, K.A., Overpeck, J.T., Otto-Bliesner, B., Heil, C.W., King, J., Scholz, C.A., Peck, J., 2015. The time-transgressive termination of the African Humid Period. Nature Geoscience 8, 140-144.

Smol, J.P., 2008. Pollution of lakes and rivers: a paleoenvironmental perspective (2nd edition). Blackwell Publishing, Oxford.

Stebich, M., Rehfeld, K., Schlütz, F., Tarasov, P.E., Liu, J., Mingram, e., 2015. Holocene vegetation and climate dynamics of NE China based on the pollen record from Sihailongwan Maar Lake. Quaternary Science Reviews 124, 275-289.

Sun, X., Wang, F., Song, C., 1996. Pollen-climate response surfaces of selected taxa from Northern China. Science in China (Series D) 39, 486-493.

Sundaram, S., Yin, Q., Berger, A., Muri, H., 2012. Impact of ice sheet induced North Atlantic oscillation on East Asian summer monsoon during an interglacial 500,000 years ago. Climate Dynamics 39, 1093-1105.

Törnqvist, T.E., Hijma, M.P., 2012. Links between early Holocene ice-sheet decay, sea-level rise and abrupt climate change. Nature Geoscience 5, 601-606.

Wang, B., 2006. The Asian Monsoon. Springer Verlag Berlin.

Wang, S., Lü, H., Liu, J., Negendank, J.F.W., 2007. The early Holocene optimum inferred from a high-resolution pollen record of Huguangyan Maar Lake in southern China. Chinese Science Bulletin 52, 2829-2836.

Wang, X., Chu, G., Sheng, M., Zhang, S., Li, J., Chen, Y., Tang, L., Su, Y., Pei, J., Yang, Z., 2016. Millennial-scale Asian summer monsoon variations in South China since the last deglaciation. Earth and Planetary Science Letters 451, 22-30.

Wang, Y., Cheng, H., Edwards, R.L., He, Y., Kong, X., An, Z., Wu, J., Kelly, M.J., Dykoski, C.A., Li, X., 2005. The Holocene Asian Monsoon: Links to solar changes and North Atlantic climate. Science 308, 854-857.

Wen, R., Xiao, J., Chang, Z., Zhai, D., Xu, Q., Li, Y., Itoh, S., 2010. Holocene precipitation and temperature variations in the East Asian monsoonal margin from pollen data from Hulun Lake in northeastern Inner Mongolia, China. Boreas 39, $262-272$. 
Wu, X., Zhang, Z., Xu, X., Shen, J., 2012. Asian summer monsoonal variations during the Holocene revealed by Huguangyan maar lake sediment record. Palaeogeography, Palaeoclimatology, Palaeoecology 323-325, 13-21.

Xiao, J., Wu, J., Si, B., Liang, W., Nakamura, T., Liu, B., Inouchi, Y., 2006. Holocene climate changes in the monsoon/arid transition reflected by carbon concentration in Daihai Lake of Inner Mongolia. The Holocene 16, 551-560.

Xiao, J., Xu, Q., Nakamura, T., Yang, X., Liang, W., Inouchi, Y., 2004. Holocene vegetation variation in the Daihai Lake region of north-central China: a direct indication of the Asian monsoon climatic history. Quaternary Science Reviews 23, 1669-1679.

Xie, S., Evershed, R.P., Huang, X., Zhu, Z., Pancost, R.D., Meyers, P.A., Gong, L., Hu, C., Huang, J., Zhang, S., Gu, Y., Zhu, J., 2013. Concordant monsoon-driven postglacial hydrological changes in peat and stalagmite records and their impacts on prehistoric cultures in central China. Geology 41, 827-830.

Yan, H., Sun, L., Wang, Y., Huang, W., Qiu, S., Yang, C., 2011. A record of the Southern Oscillation Index for the past 2,000 years from precipitation proxies. Nature Geoscience 4, 611-614.

Zhao, H., Chen, F.-H., Li, S.-H., Wintle, A.G., Fan, Y.-X., Xia, D.-S., 2007. A record of Holocene climate change in the Guanzhong Basin, China, based on optical dating of a loess-palaeosol sequence. The Holocene 17, 1015-1022.

Zhao, Y., Yu, Z., Chen, F., Zhang, J., Yang, B., 2009. Vegetation response to Holocene climate change in monsoon-influenced region of China. Earth-Science Reviews 97, 242-256.

Zhou, W., Song, S., Burr, G., Jull, A.J.T., Lu, X., Yu, H., Cheng, P., 2007. Is there a time-transgressive Holocene Optimum in the East Asian monsoon area? Radiocarbon 49, 865-875.

Zhou, W., Yu, X., Jull, A.J.T., Burr, G., Xiao, J.Y., Lu, X., Xian, F., 2004. High-resolution evidence from southern China of an early Holocene optimum and a mid-Holocene dry event during the past 18,000 years. Quaternary Research 62, $39-48$. 
473 Zhou, X., 2012. Asian monsoon precipitation changes and the Holocene methane $474 \quad$ anomaly. The Holocene 22, 731-738.

475 Zhu, C., Ma, C., Yu, S., Tang, L., Zhang, W., Lu, X., 2010. A detailed pollen record of 476 vegetation and climate changes in Central China during the past 16000 years. $477 \quad$ Boreas 39, 69-76.

478 


\section{Figure Captions}

Figure 1 Study areas. Maps showing the locations of our sampling site (red circle) (a) and cores we drilled (b). Map was generated with Ocean Data View 4.0.

Figure 2 Instrumental climate data (1958-2000) from Bei'an Station $\left(48^{\circ}=17^{\prime} \mathrm{N}\right.$, 12631' E), Heilongjiang, China (data from China Meteorological Administration).

Figure 3 AMS ${ }^{14} \mathrm{C}$ dating of the sediments.

Figure 4 Comparison between the age of the volcanic ash layer from historical documents (Chen et al., 1999) and AMS ${ }^{14} \mathrm{C}$ dating. Because magnetic susceptibility of volcanic ash is significantly higher than other sediment layers in the lake, the ash layer was detected by high magnetic susceptibility.

Figure 5 Comparison of $\mathrm{LOI}_{550^{\circ} \mathrm{C}}$ between Core TC1 and TC2.

Figure 6 Comparison between $\mathrm{LOI}_{550^{\circ} \mathrm{C}}$ and TOC, and tree pollen percentages.

Figure 7 Comparison of Tree pollen percentages in Tianchi Lake with other monsoon proxies and $30^{\circ} \mathrm{N}$ summer insolation (black line) (Laskar et al., 2004). Moisture changes across eastern monsoonal China (Zhao et al., 2009) is shown in magenta, East Asian summer monsoon index (Zhou, 2012) in red, and stalagmite $\delta^{18} \mathrm{O}$ of Dongge Cave (Wang et al., 2005) in green.

Figure 8 Pollen percentage for typical taxa.

Figure 9 Comparison pollen records in sediments of different sites in the EAM region. a. Maps showing the location of our sampling site (red circle) and other proxies used in the present study (red triangles show sites of proxies used in Figure 9b, blue triangles show sites of four loess sections, base map is modified from Zhou, 2012). b. Pollen records in sediments of different sites in the EAM region. Details of data are shown in Table 2 and Table 3. Red and blue lines show records from sites at around $40^{\circ} \mathrm{N}$ and $48^{\circ} \mathrm{N}$, respectively. The light green arrow indicates the northward expansion of the HO. c. Correlation between the initiation of the $\mathrm{HO}$ and latitudes in the EAM region. Red diamonds represent the locations where the HO initiation data are used to build the regression model, green lines 

show the uncertainties of the $\mathrm{HO}$ initial ages. Blue circles represent the four locations where paleosol layers were dated and used to make prediction of the initiation of the $\mathrm{HO}$. 
Table 1 List of sites of pollen records in eastern China used in this study.

\begin{tabular}{|c|c|c|c|c|c|c|c|c|}
\hline Site Name & Latitude & Longitude & Proxy & $\begin{array}{l}\text { Dating } \\
\text { Method }\end{array}$ & Dating Material & $\begin{array}{c}\text { Number of } \\
\text { Dates }\end{array}$ & $\begin{array}{l}\text { Age range } \\
\text { (Cal a BP) }\end{array}$ & References \\
\hline $\begin{array}{l}\text { Huguangyan Maar } \\
\text { Lake }\end{array}$ & $21^{\circ} 9^{\prime} \mathrm{N}$ & $110^{\circ} 17^{\prime} \mathrm{E}$ & $\begin{array}{l}\text { Tropical tree } \\
\text { pollen }\end{array}$ & AMS ${ }^{14} \mathrm{C}$ & leaves, seeds; TOC & 15 & $13,000-0$ & (Wang et al., 2007) \\
\hline Dahu Peat & $24^{\circ} 15^{\prime} \mathrm{N}$ & $115^{\circ} 2^{\prime} \mathrm{E}$ & $\begin{array}{l}\text { Evergreen tree } \\
\text { pollen }\end{array}$ & AMS ${ }^{14} \mathrm{C}$ & plant fragments & 17 & $16,500-0$ & (Zhou et al., 2004) \\
\hline Dajiuhu Peat & $31^{\circ} 29^{\prime} 27^{\prime \prime N}$ & $109^{\circ} 59^{\prime} 45^{\prime \prime} \mathrm{E}$ & $\begin{array}{l}\text { Evergreen tree } \\
\text { pollen }\end{array}$ & AMS ${ }^{14} \mathrm{C}$ & Peat cellulose & 10 & $15,760-0$ & (Zhu et al., 2010) \\
\hline Gonghai Lake & $38^{\circ} 54^{\prime} \mathrm{N}$ & $112^{\circ} 14^{\prime} \mathrm{E}$ & $\begin{array}{l}\text { Broadleaf tree } \\
\text { pollen }\end{array}$ & AMS ${ }^{14} \mathrm{C}$ & Stem, leaf & 25 & $14,700-0$ & (Chen et al., 2015) \\
\hline Daihai Lake & $40^{\circ} 35^{\prime} \mathrm{N}$ & $112^{\circ} 40^{\prime} \mathrm{E}$ & Tree pollen & AMS ${ }^{14} \mathrm{C}$ & TOC & 8 & $12,000-0$ & (Xiao et al., 2004) \\
\hline Bayanchagan Lake & $41^{\circ} 39^{\prime} \mathrm{N}$ & $115^{\circ} 12^{\prime} 36^{\prime \prime} \mathrm{E}$ & Tree pollen & $\mathrm{AMS}{ }^{14} \mathrm{C}$ & TOC, seeds & 9 & $14,000-0$ & (Jiang et al., 2006) \\
\hline $\begin{array}{c}\text { Sihailongwan Maar } \\
\text { Lake }\end{array}$ & $42^{\circ} 17^{\prime} \mathrm{N}$ & $126^{\circ} 36^{\prime} \mathrm{E}$ & Tree pollen & $\begin{array}{l}\text { AMS }{ }^{14} \mathrm{C} \text {, } \\
\text { varve count }\end{array}$ & $\begin{array}{c}\text { leaves, wood, seeds \& } \\
\text { moss }\end{array}$ & 36 & $15,287-0$ & (Stebich et al., 2015) \\
\hline Moon Lake & $47^{\circ} 30^{\prime} 25^{\prime \prime} \mathrm{N}$ & $120^{\circ} 52^{\prime} 05^{\prime \prime} \mathrm{E}$ & Tree pollen & $\mathrm{AMS}{ }^{14} \mathrm{C}$ & plant fragments, TOC & 17 & $14,000-0$ & (Liu et al., 2010) \\
\hline Tianchi Lake & $48^{\circ} 44^{\prime} 24^{\prime \prime} \mathrm{N}$ & $126^{\circ} 00^{\prime \prime} \mathrm{E}$ & Tree pollen & AMS ${ }^{14} \mathrm{C}$ & leaves, seeds, TOC & 15 & $13,120-0$ & This study \\
\hline
\end{tabular}


Table 2 AMS ${ }^{14} \mathrm{C}$ ages from Tianchi Lake.

\begin{tabular}{|c|c|c|c|c|c|}
\hline $\begin{array}{l}\text { Laboratory } \\
\text { number }\end{array}$ & $\begin{array}{l}\text { Sample } \\
\text { number }\end{array}$ & $\begin{array}{l}\text { Dated } \\
\text { material }\end{array}$ & Depth $(\mathrm{cm})$ & $\begin{array}{l}\text { Conventional } \\
\text { age (a BP) }\end{array}$ & $\begin{array}{c}\text { Calibrated age } \\
\text { (a BP) }\end{array}$ \\
\hline 10110 & TC-32 & $\begin{array}{c}\text { Bulk organic } \\
\text { carbon }\end{array}$ & 16 & $200 \pm 25$ & $144-215$ \\
\hline 13190 & TC-49 & Seeds & 24.5 & $730 \pm 25$ & $655-701$ \\
\hline 13194 & TC-58 & Seeds & 29 & $1,560 \pm 30$ & $1,387-1,529$ \\
\hline 10111 & TC-83 & $\begin{array}{l}\text { Bulk organic } \\
\text { carbon }\end{array}$ & 41.5 & $2,740 \pm 30$ & $2,765-2,885$ \\
\hline 13191 & TC-130 & Leaves & 65 & $4,190 \pm 30$ & $4,622-4,744$ \\
\hline 13192 & TC-166 & Leaves & 83 & $5,580 \pm 35$ & $6,297-6,414$ \\
\hline 10112 & TC-202 & $\begin{array}{c}\text { Bulk organic } \\
\text { carbon }\end{array}$ & 101 & $6,350 \pm 30$ & $7,240-7,331$ \\
\hline 10114 & TC2-1 & $\begin{array}{c}\text { Bulk organic } \\
\text { carbon }\end{array}$ & 120 & $7,170 \pm 30$ & $7,943-8,024$ \\
\hline 10113 & TC-294 & $\begin{array}{c}\text { Bulk organic } \\
\text { carbon }\end{array}$ & 147 & $8,130 \pm 30$ & $8,999-9,133$ \\
\hline 10115 & TC2-84 & $\begin{array}{l}\text { Bulk organic } \\
\text { carbon }\end{array}$ & 161 & $8,810 \pm 30$ & $9,694-9,938$ \\
\hline 13194 & TC2-116 & Seeds & 177 & $9,080 \pm 30$ & $10,197-10,258$ \\
\hline 13195 & TC2-130 & Seeds & 184 & $11,180 \pm 35$ & $12,989-13,115$ \\
\hline 10116 & TC2-156 & $\begin{array}{c}\text { Bulk organic } \\
\text { carbon }\end{array}$ & 197 & $11,860 \pm 30$ & $13,575-13,758$ \\
\hline $13196^{*}$ & TC2-156 & Leaves & 197 & $10,660 \pm 35$ & $12,566-12,702$ \\
\hline
\end{tabular}

*Because the sample is at the bottom of the core, we suspect it has been contaminated by leaves from upper layers, as we have observed that some leaves were carried by the corer to the bottom of the core. 
Table 3 Ages corresponding to the beginning of the Holocene Optimum recorded in loess sections from OSL dating and our predictions.

\begin{tabular}{ccccc}
\hline $\begin{array}{c}\text { Site } \\
\text { Name }\end{array}$ & Latitude & $\begin{array}{c}\text { OSL age } \\
(\mathrm{BP})\end{array}$ & $\begin{array}{c}\text { Predicted age (BP) by } \\
\text { our method }\end{array}$ & Reference \\
\hline \multirow{2}{*}{ Yaoxian } & $34^{\circ}{ }^{\circ} 53^{\prime} \mathrm{N}$ & $8,420 \pm 880 \mathrm{yrs}$ & $8,420 \mathrm{yrs}$ & (Zhao et al., 2007) \\
& & $8,440 \pm 590 \mathrm{yrs}$ & & (Jia et al., 2011) \\
JYC & $34^{\circ} 27^{\prime} \mathrm{N}$ & $8,310 \pm 340 \mathrm{yrs}$ & $8,495 \mathrm{yrs}$ & (Lu et al., 2013) \\
Yulin & $38^{\circ} 200^{\prime} \mathrm{N}$ & $\sim 7,800 \mathrm{yrs} *$ & $7,830 \mathrm{yrs}$ & (Lu et al., 2013) \\
Luochuan & $35^{\circ} 43^{\prime} \mathrm{N}$ & $\sim 8,370 \mathrm{yrs} *$ & $8,280 \mathrm{yrs}$ & \\
\hline
\end{tabular}

*HO recorded in Yulin and Luochuan loess sections are estimated from changes in magnetic susceptibility and total organic carbon concentrations. 


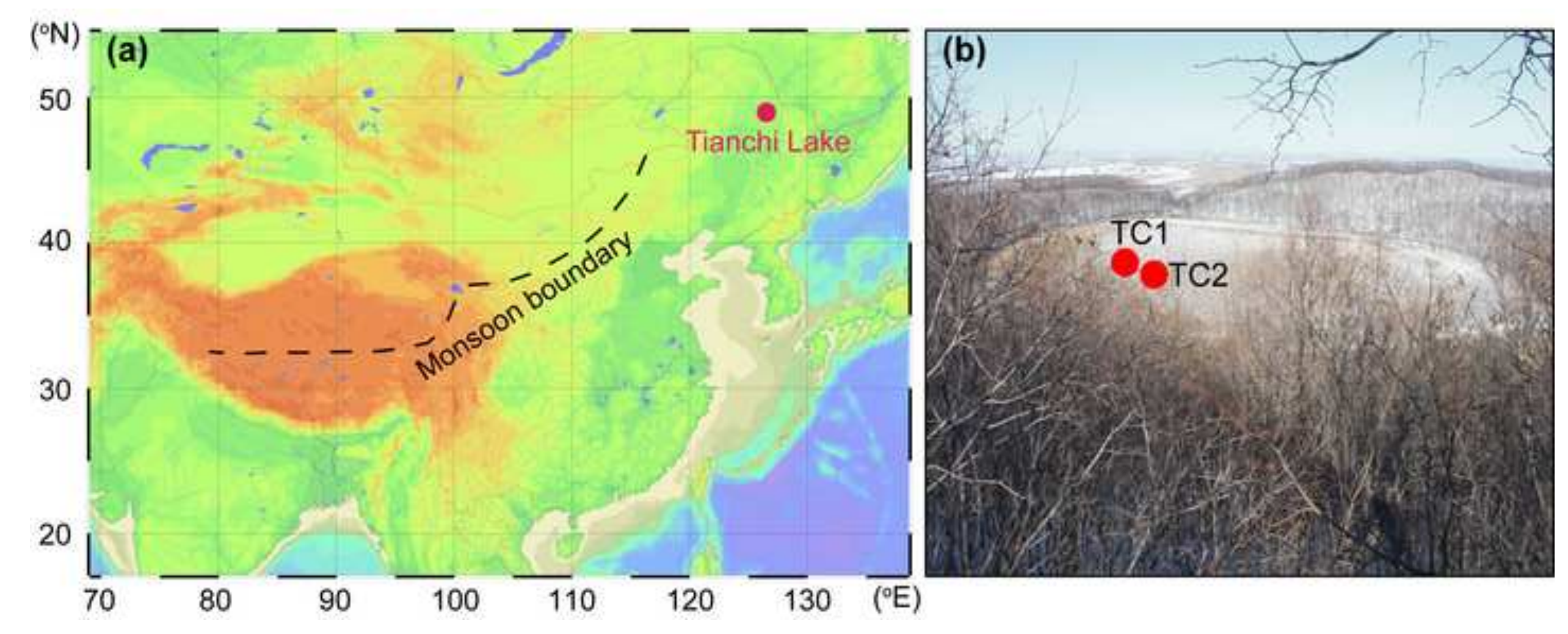




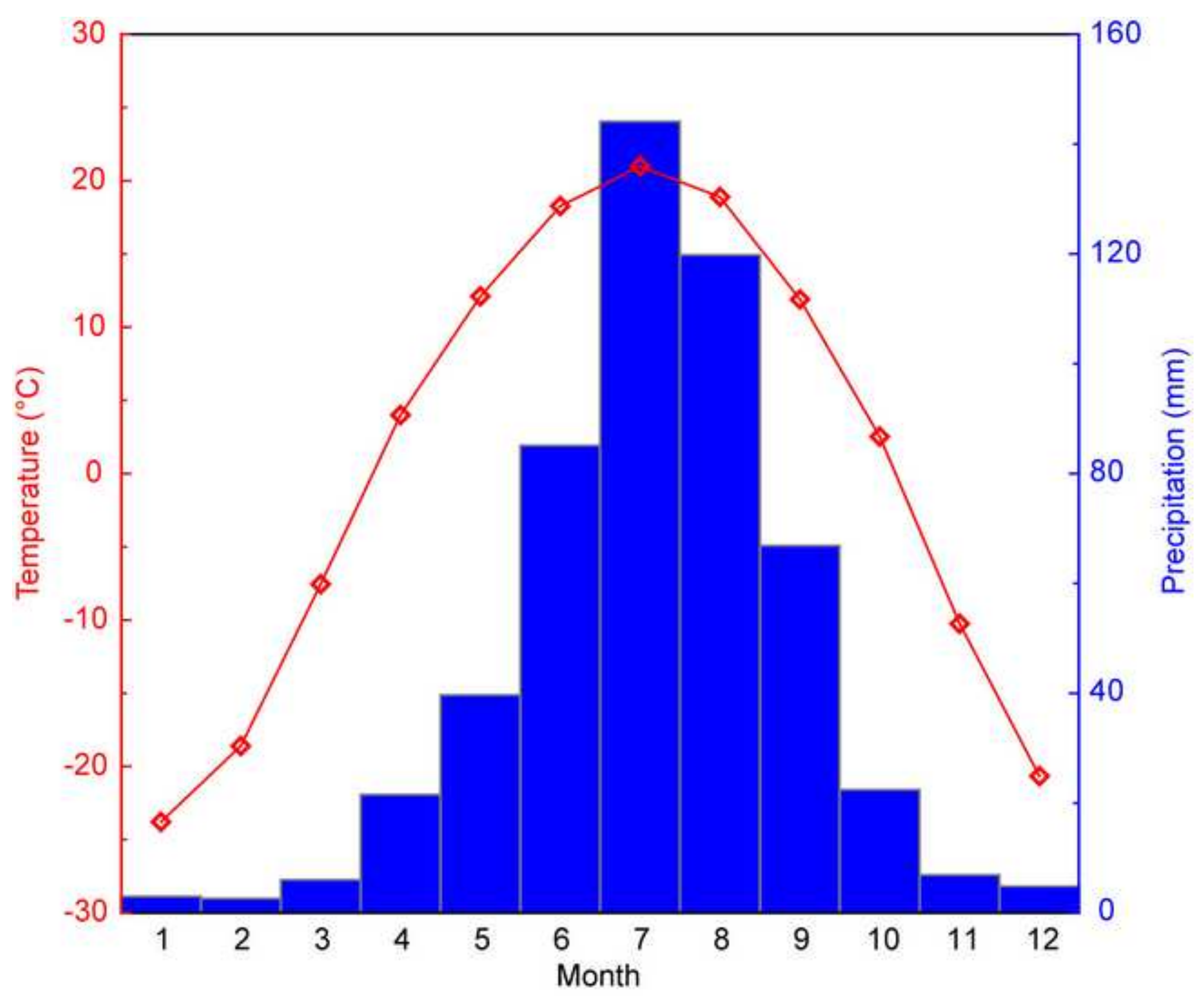




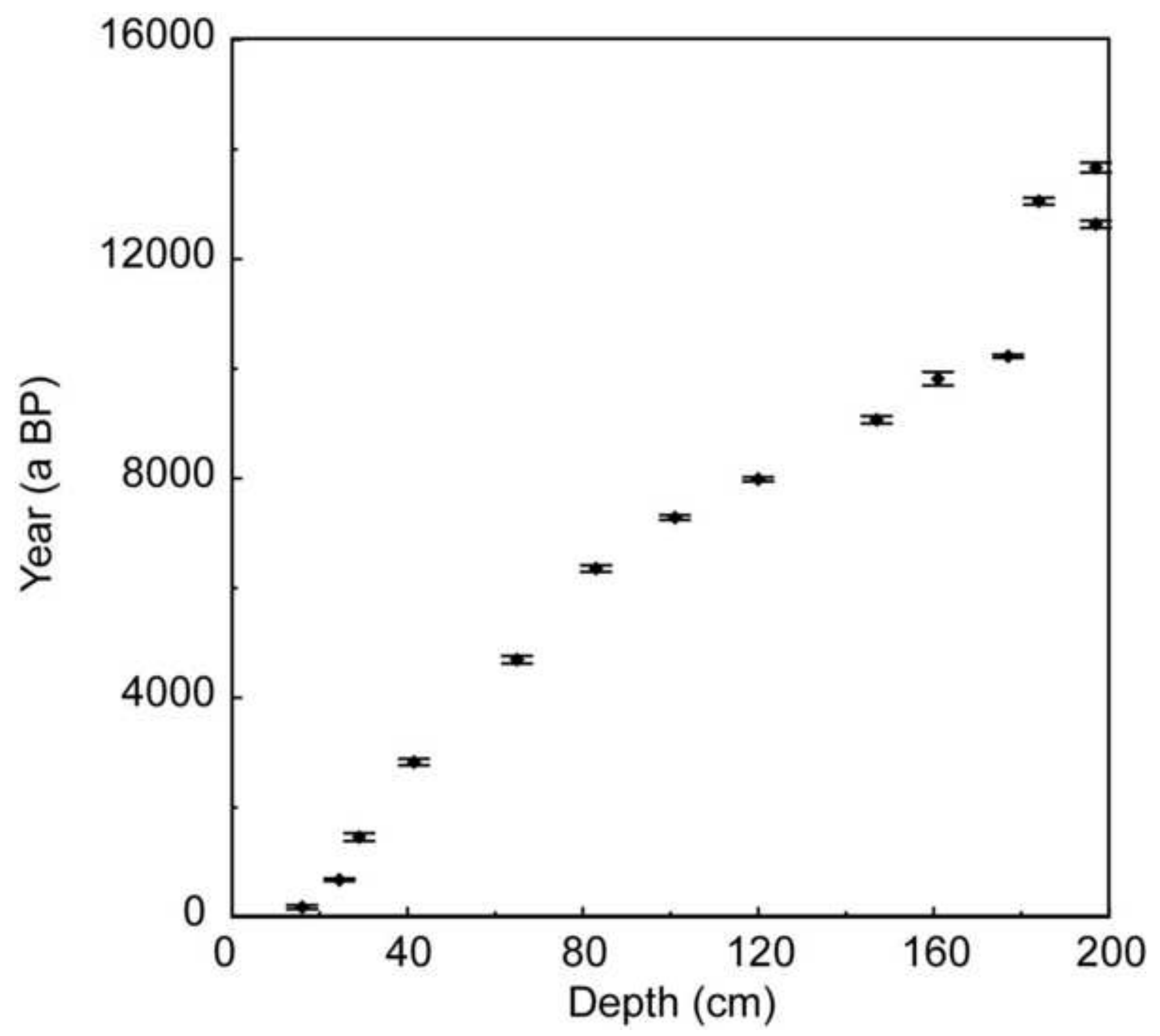


Figure 4

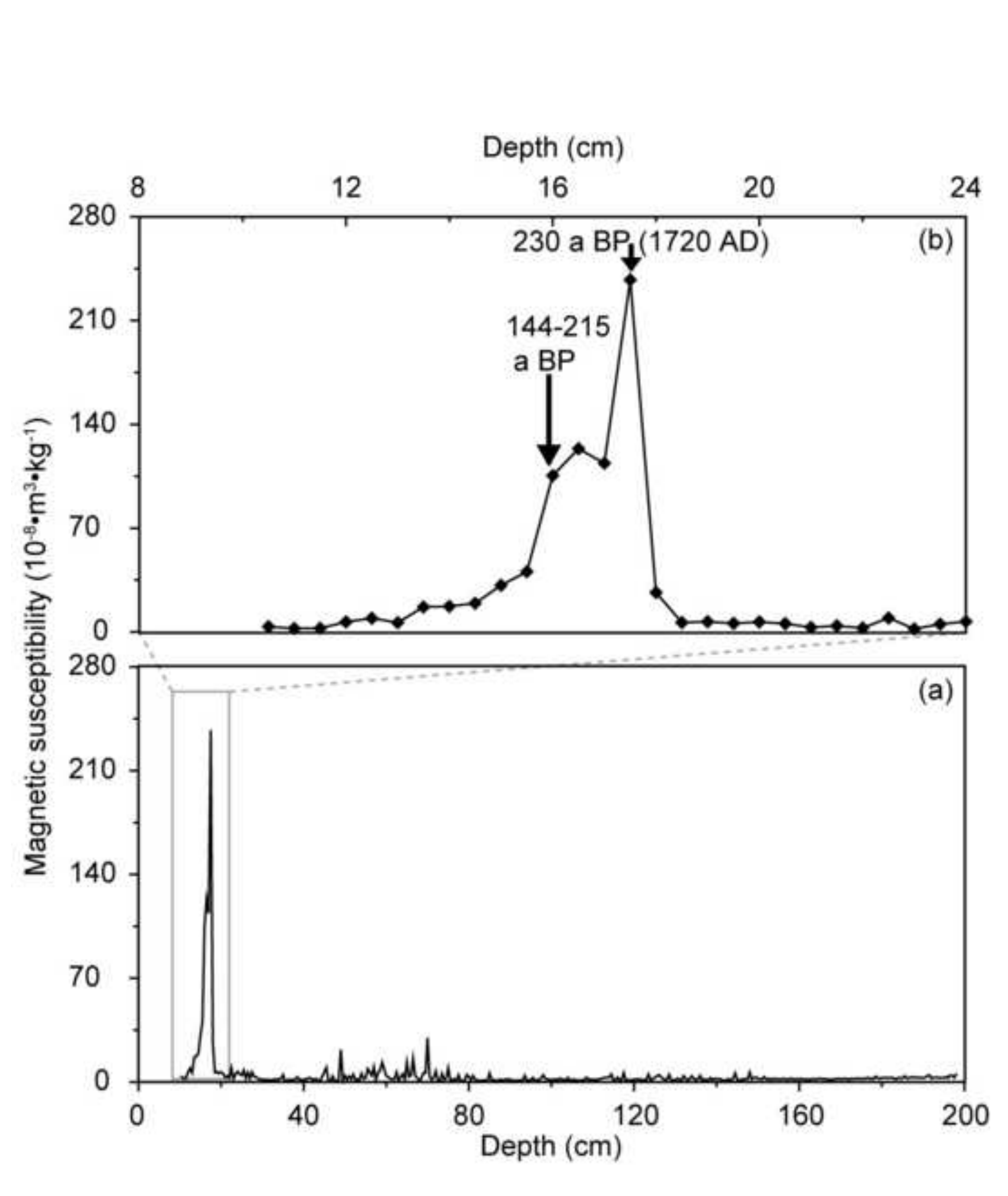

Depth $(\mathrm{cm})$ 


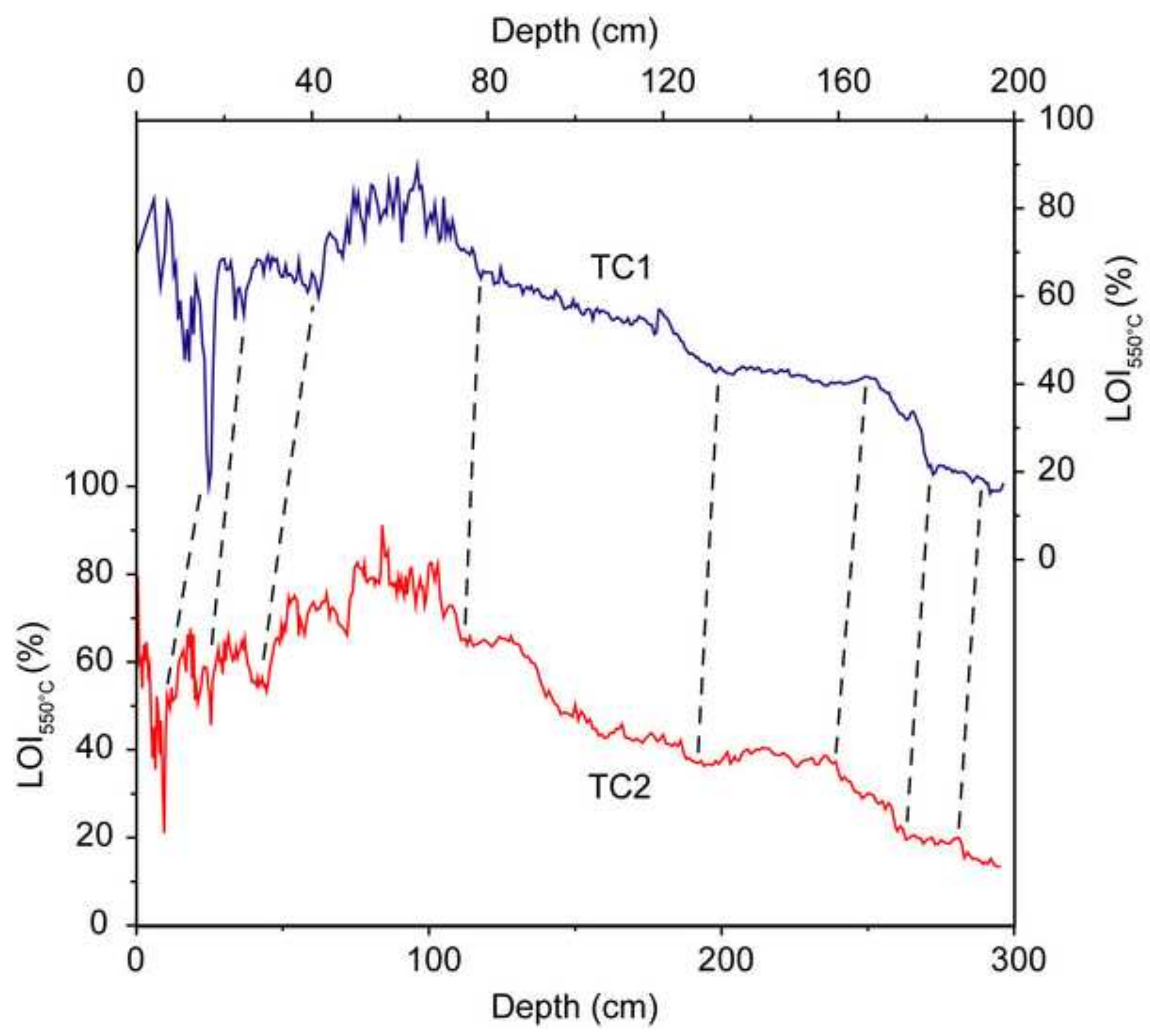



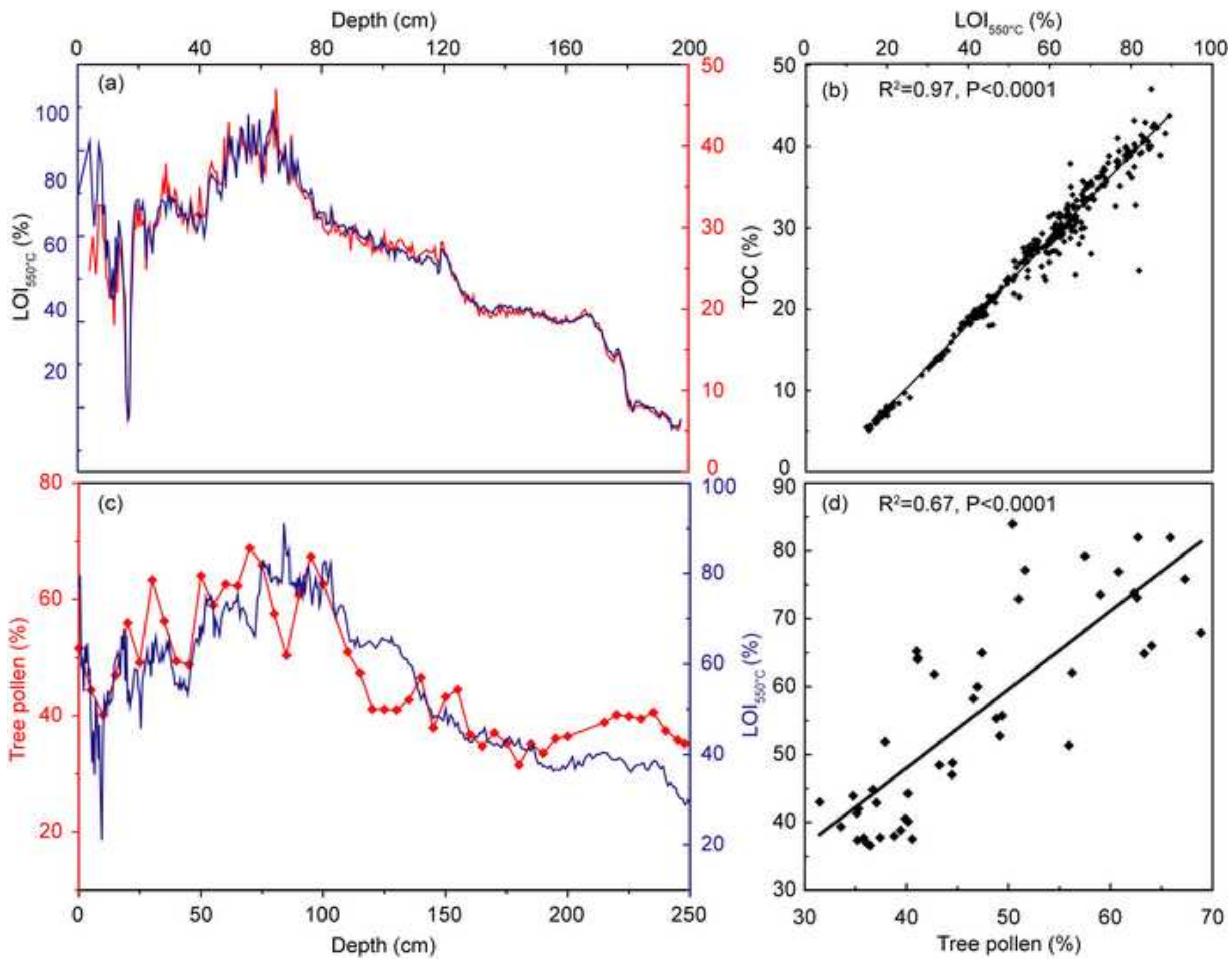


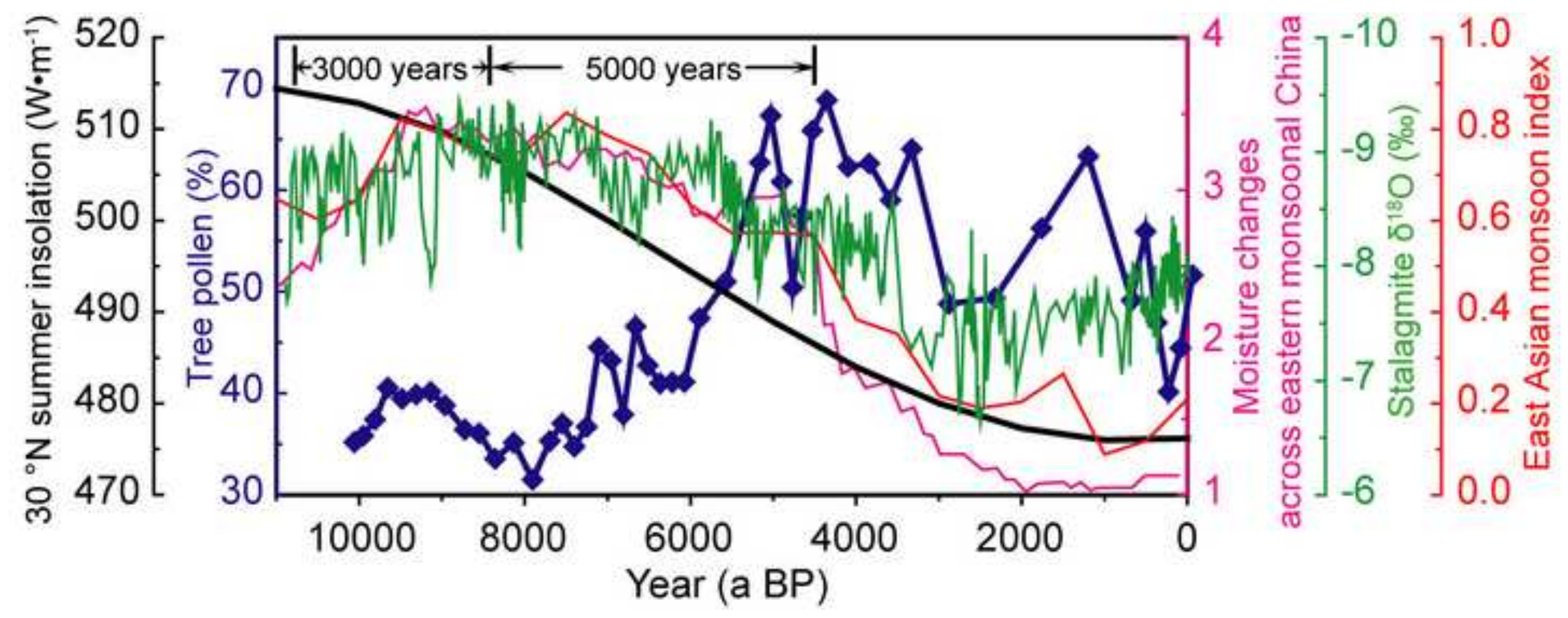




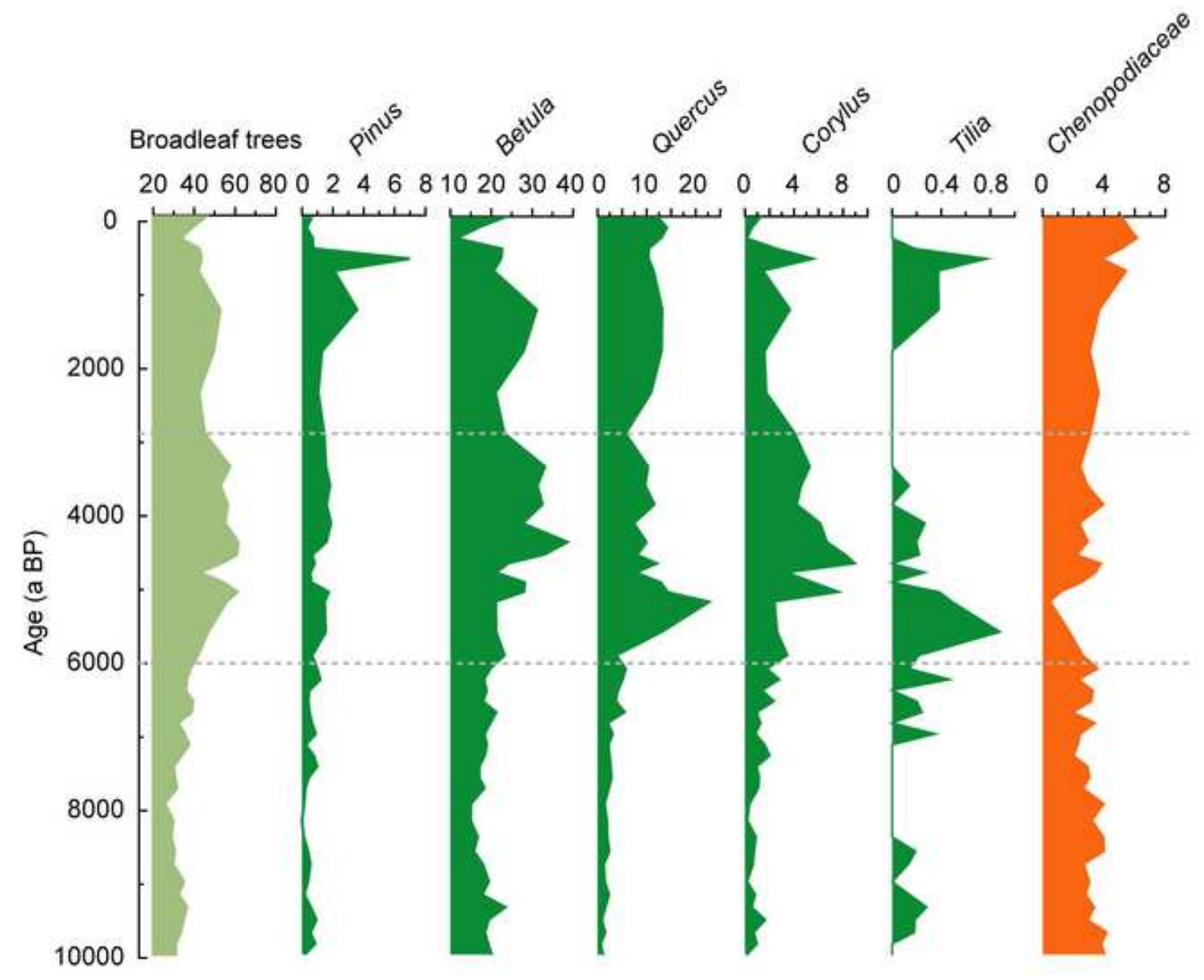



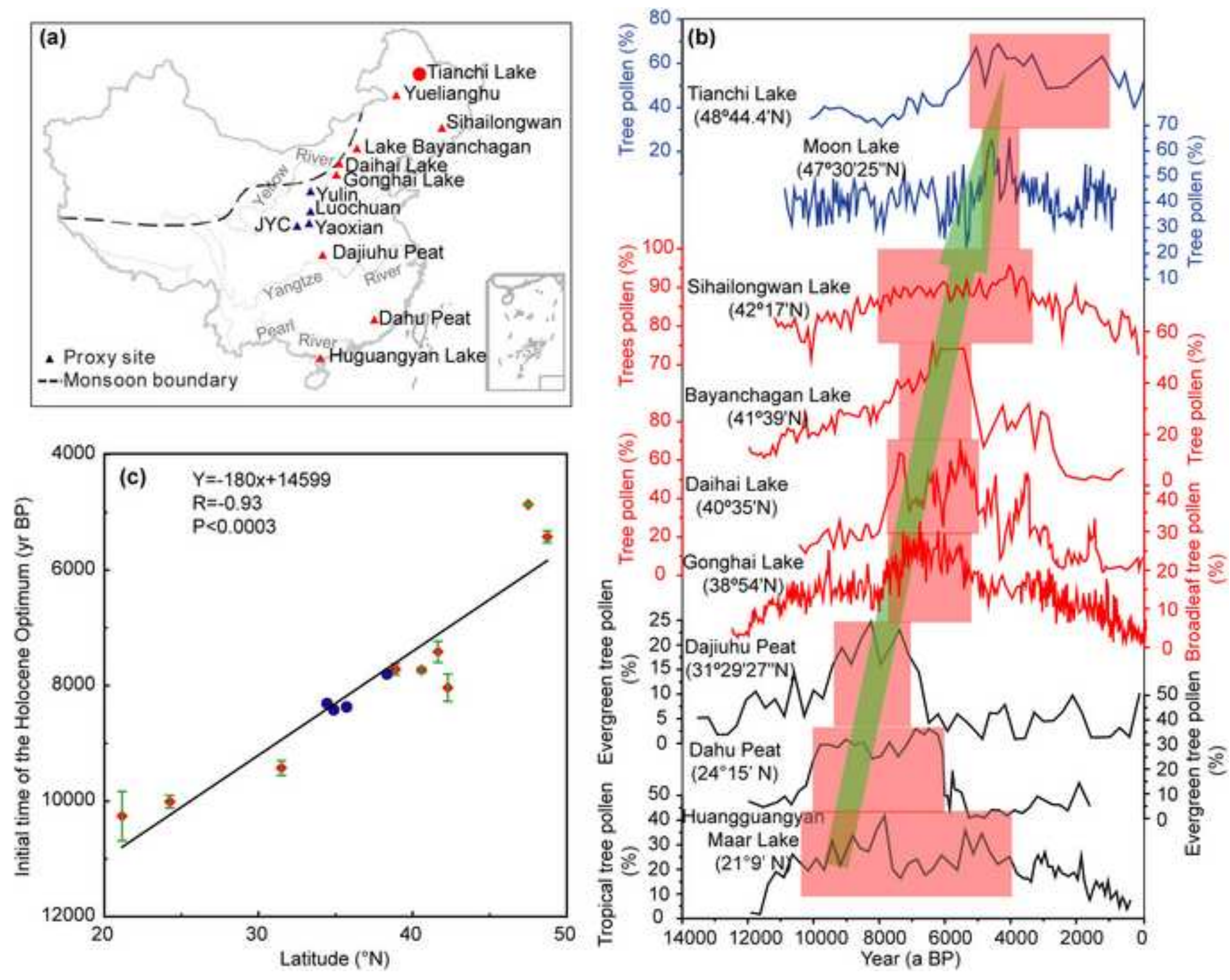